\title{
Effect of Hyperbaric Oxygen Therapy on whole blood cyanide concentrations in carbon monoxide intoxicated patients from fire accidents
}

Pia Lawson-Smith*1, Erik C Jansen*2, Linda Hilsted ${ }^{* 3}$ and Ole Hyldegaard*1,2

\begin{abstract}
Background: Hydrogen cyanide ( $\mathrm{HCN}$ ) and carbon monoxide (CO) may be important components of smoke from fire accidents. Accordingly, patients admitted to hospital from fire accidents may have been exposed to both HCN and CO. Cyanide (CN) intoxication results in cytotoxic hypoxia leading to organ dysfunction and possibly death. While several reports support the use of hyperbaric oxygen therapy $(\mathrm{HBO})$ for the treatment of severe $\mathrm{CO}$ poisoning, limited data exist on the effect of $\mathrm{HBO}$ during $\mathrm{CN}$ poisoning. $\mathrm{HBO}$ increases the elimination rate of $\mathrm{CO}$ haemoglobin in proportion to the increased oxygen partial pressure and animal experiments have shown that in rats exposed to CN intoxication, $\mathrm{HBO}$ can increase the concentration of $\mathrm{CN}$ in whole blood.
\end{abstract}

Objective: The purpose of the present study was to determine whole blood $\mathrm{CN}$ concentrations in fire victims before and after $\mathrm{HBO}$ treatment.

Materials and methods: The patients included were those admitted to the hospital because of CO intoxication, either as fire victims with smoke inhalation injuries or from other exposures to CO. In thirty-seven of these patients we measured CN concentrations in blood samples, using a Conway/microdiffusion technique, before and after $\mathrm{HBO}$. The blood samples consisted of the remaining $2 \mathrm{~mL}$ from the arterial blood gas analysis. CN concentration in blood from fire victims was compared to 12 patients from non-fire accidents but otherwise also exposed to CO intoxication.

Results: The mean WB-CN concentration before patients received HBO did not differ significantly between the two groups of patients $(p=0.42)$. The difference between WB-CN before and after HBO did not differ significantly between the two groups of patients $(p=0.7)$. Lactate in plasma before and after did not differ significantly between the two groups of patients. Twelve of the 25 fire patients and one of the non-fire patients had been given a dose of hydroxycobalamin before $\mathrm{HBO}$.

Discussion and Conclusion: CN concentrations in blood from patients admitted to hospital with CO intoxication and smoke inhalation exposure did not differ significantly from controls. Accordingly, we were not able to detect any changes in $\mathrm{CN}$ concentrations in blood after treatment with $\mathrm{HBO}$.

Trial Registration: ClinicalTrials.gov identifier: NCT00280579

\section{Introduction}

Reports have shown that patients admitted to hospital from fire accidents may have been exposed to cyanide

\footnotetext{
*Correspondence: lawson_smith@dadlnet.dk, erik.jansen@rh.regionh.dk, linda.hilsted@rh.regionh.dk, ole.hyldegaard@rh.regionh.dk

${ }^{1}$ Laboratory of Hyperbaric Medicine, Department of Anesthesia, Center of Head and Orthopedics, Rigshospitalet, Blegdamsvej, Copenhagen, 2100, Denmark

2 Center of Hyperbaric Medicine, Department of Anesthesia, Center of Head and Orthopedics, Rigshospitalet, Blegdamsvej, Copenhagen, 2100, Denmark Full list of author information is available at the end of the article
}

(CN) gases as well as carbon monoxide (CO) [1-3]. Baud showed [4] that persons from fire accidents were both poisoned with $\mathrm{CN}$ and $\mathrm{CO}$. $\mathrm{CN}$ is a potent intracellular poison which can be developed from incomplete combustion of materials containing nitrogen in fire accidents [5]. When fire temperatures reach $315^{\circ} \mathrm{C}\left(600^{\circ} \mathrm{F}\right) \mathrm{CN}$ develops in the form of hydrogen cyanide (HCN) [1]. In the cell $\mathrm{CN}$ binds to the enzyme cytochrome oxidase a, a3 (CCO) (i.e. complex IV in the mitochondrial electron transport chain) similar to $\mathrm{CO}[6]$; thus stopping the 
mitochondrial respiration chain and the formation of adenosine triphosphate (ATP).

According to several clinical studies, there is general agreement that $\mathrm{HBO}$ treatment is recommended in case of $\mathrm{CO}$ poisoning if the patient suffers from severe neurological symptoms or has been exposed to $\mathrm{COHb}$ concentrations higher than 25\%. The current treatment indications for $\mathrm{HBO}$ therapy during $\mathrm{CO}$ poisoning in Denmark is in alignment with the recommendations as stated above [7-10]. Current treatment of $\mathrm{CN}$ poisoning is based on treating basic symptoms combined with hydroxycobalamin (Cyanokit', OHCob) given i.v. [11,12]. $\mathrm{OHCob}$ i.v. reacts with any $\mathrm{CN}$ present in the blood stream and creates cyanocobalamin (B12 vitamin) a nontoxic substance that is excreted via the kidneys [13]. Whether OHCob can pass through the vascular wall and the blood-brain barrier to induce a direct detoxification effect within the central nervous system remains to be investigated [14]. However a French study by Astier et al demonstrated that $\mathrm{OHCob}$ may enter the intracellular compartment under in-vitro conditions [15].

$\mathrm{HBO}$ is recommended especially when supportive measures and other $\mathrm{CN}$ antidotes fail [16-18]. $\mathrm{HBO}$ is known to facilitate the dissociation of $\mathrm{CO}$ from cytochrome oxidase a, a3 in the mitochondrial respiratory chain [19].

In an animal model we have previously shown that HBO has an effect on the concentration of whole-blood cyanide (WB-CN) which increased significantly in comparison to untreated controls when measured 2 hours after HBO treatment [20]. Accordingly, the primary purpose of this clinical protocol was to measure whether $\mathrm{HBO}$ treatment in the $\mathrm{CO}$ and $\mathrm{CN}$ exposed patient would have the same effect on WB-CN in humans as demonstrated in the animal experiments. The secondary purpose of this clinical protocol was to determine how many patients from fires were $\mathrm{CN}$ poisoned above the toxic concentration levels defined as a whole-blood concentration higher than $39 \mu \mathrm{mol} / \mathrm{L}$ [11].

\section{Methods}

The Local Ethics Committee approved the study. The study is registered at ClinicalTrials.gov identifier: NCT00280579. We studied 25 fire victims, aged 18 years or older, who were admitted to the level-1 trauma centre at Copenhagen University Hospital, Rigshospitalet for treatment of $\mathrm{CO}$ poisoning and smoke inhalation injury between January 2006 and November 2009. Twelve control subjects (i.e patients from non-fire accidents who were receiving $\mathrm{HBO}$ treatment for other causes such as suicide attempts or accidental gas inhalation) were also included.

Time sequence of blood sampling: Immediately before and after HBO therapy two $2 \mathrm{~mL}$ arterial blood samples were obtained from the patients. One sample was used immediately to determine the blood lactate concentration using the Radiometer ABL version 725 (Radiometer A/S, Copenhagen, Denmark). Any air bubbles were carefully removed from the other blood sample, and the syringe was tightly sealed and stored at $-25^{\circ} \mathrm{C}$ until WB-CN concentration analysis the next day. Accordingly, WB-CN concentrations were determined before and after the first $\mathrm{HBO}$ treatment session. Two hours after the first acute $\mathrm{HBO}$ treatment session, a third blood sample for WB-CN concentration measurement was obtained. As controls we used blood samples from non-fire patients, collected and stored in the same way.

\section{Whole blood $\mathrm{CN}$ measurements}

$\mathrm{CN}$ was measured using a Conway/microdiffusion method, where $\mathrm{CN}$ is liberated from blood in a gaseous phase and subsequently bound to OHCob forming cyanocobalamin [21]. The Conway chambers (Bel-Art products, Pequannock, NJ, USA) were placed on a heating plate and all reactions took place at $45^{\circ} \mathrm{C}$. In the outer ring $1 \mathrm{~mL}$ blood was mixed with $1 \mathrm{~mL}$ of $5 \%$ Triton X 100 and $2 \mathrm{~mL}$ of $50 \mu \mathrm{M} \mathrm{OHCob}$ in $0.067 \mathrm{M} \mathrm{KH}_{2} \mathrm{PO}_{4}$ was placed in the inner ring. Immediately before closing the chamber, $2 \mathrm{~mL}$ of $6.55 \mathrm{M}$ sulphuric acid was added in the outer ring. In this acidic solution, the $\mathrm{CN}$ is in the protonated form, $\mathrm{HCN}$, with a boiling point of $25.6^{\circ} \mathrm{C}$. Thus any $\mathrm{CN}$ bound or free from the blood evaporates and binds to the $\mathrm{OHCob}$ in the inner ring and forms cyanocobalamin. Accordingly, previously given $\mathrm{OHCob}$ should not interfere with measurements of the cyanide concentrations in whole blood [21] After 30 min the solution in the absorbent chamber was aspirated and absorption at $361 \mathrm{~nm}$ was read (Shimadzu UV-1601 spectrophotometer, Shimadzu, Kyoto, Japan). The absorption increased linearly with the concentration of $\mathrm{CN}$ in the blood sample up to $100 \mu \mathrm{mol} / \mathrm{L}$. All measurements were performed in duplicate and each series included a blank and three standards of 20,40 , and $100 \mu \mathrm{mol} / \mathrm{L}$ in $1 \mathrm{~mol} / \mathrm{L} \mathrm{KOH}$. The lower limit of quantification was estimated to $20 \mu \mathrm{mol} / \mathrm{L}$.

\section{Data analysis and statistics}

Descriptive data are presented with mean and standard error of mean (SEM). Groups were compared with the Mann-Whitney test using SAS for Windows, version 9.1 (SAS Institute Inc., Cary, USA). P-values for $\mathrm{CN}$ concentrations are also presented with a quantification limit adjusted Mann-Whitney test, where all values below 20 $\mu \mathrm{mol} / \mathrm{L}$ are analysed as $10 \mu \mathrm{mol} / \mathrm{L}$.

\section{Results \\ Effect of $\mathrm{CN}$ poisoning on WB-CN during $\mathrm{HBO}$ General patient data}

The patients' average age was 52 years. We included 37 patients of whom 19 were male and 18 female. Twentyfive patients were admitted from fire accidents and 12 
patients were admitted to the Trauma Centre facility with $\mathrm{CO}$ poisoning from non-fire accidents. The average time from accident to arrival at the Trauma Centre was 3.22 hours. The time from arrival at the Trauma Centre to initiating $\mathrm{HBO}$ was 3.7 hours. Neither the time interval from accident to arrival, nor the time interval from arrival at the Trauma Centre to $\mathrm{HBO}$ treatment were initiated, showed any significant differences among patient groups.

\section{Patients from fire accidents}

Of the 25 patients from fire accidents, 2 had a WB-CN concentration higher than $39 \mu \mathrm{mol} / \mathrm{L}$ before $\mathrm{HBO}$. OHCob was given to 12 patients, before $\mathrm{HBO}$ treatment, because of suspected cyanide poisoning.

In blood tests before and after HBO 13 showed an increase in WB-CN concentration and 10 a decrease. In the remaining two the WB-CN concentration did not change.

Of the 25 patients admitted from fire-accidents we were able to measure WB-CN concentration 2 hours after HBO therapy in 11 patients. Of these patients 2 had not received OHCob. No significant increase or decrease was observed in the 3 rd WB-CN measurement.

The mean WB-CN concentration on arrival for patients having received $\mathrm{OHCob}$ before the blood test was 15.4 $\mu \mathrm{mol} / \mathrm{L}+/$ - SEM $4.1 \mu \mathrm{mol} / \mathrm{L}$. In patients not receiving OHCob the mean was $14.33 \mu \mathrm{mol} / \mathrm{L}+/$ - SEM $1.4 \mu \mathrm{mol} / \mathrm{L}$ .The mean difference between $\mathrm{CN}$ concentration in blood before and after $\mathrm{HBO}$ in patients receiving $\mathrm{OHCob}$ was $2.1 \mu \mathrm{mol} / \mathrm{L}+/$ - SEM 1.4 $\mu \mathrm{mol} / \mathrm{L}$. Patients not receiving OHCob had a mean of $1.9 \mu \mathrm{mol} / \mathrm{L}+/-$ SEM $1.9 \mu \mathrm{mol} / \mathrm{L}$.

The mean lactate concentration on arrival for patients receiving $\mathrm{OHCob}$ was $5 \mathrm{mmol} / \mathrm{L}$ and for patients not receiving $\mathrm{OHCob} 3.7 \mathrm{mmol} / \mathrm{L}$. The mean lactate concentration after $\mathrm{HBO}$ was $1.9 \mathrm{mmol} / \mathrm{L}$ for patients receiving $\mathrm{OHCob}$ and $1.3 \mathrm{mmol} / \mathrm{L}$ for patients not receiving OHCob. See Table 1.

\section{Patients from non-fire accidents}

None of the 12 patients from non-fire accidents had a $\mathrm{CN}$ concentration in whole blood higher than $39 \mu \mathrm{mol} / \mathrm{L}$ before $\mathrm{HBO}$. OHCob was given to one patient before leaving the level-1 Trauma Centre thus before HBO. In blood tests before and after $\mathrm{HBO}$ seven patients showed an increase in WB-CN and five a decrease. Of the 12 patients from non-fire accidents we were able to measure WB-CN 2 hours after $\mathrm{HBO}$ therapy in 3 patients, of these which only 1 had received OHCob. No significant increase or decrease was observed in the 3 rd WB-CN measurement.

The mean WB-CN concentration on arrival was 12.5 $\mu \mathrm{mol} / \mathrm{L}+/$ - SEM $1.5 \mu \mathrm{mol} / \mathrm{L}$. The mean difference between $\mathrm{CN}$ concentration in whole blood before and after $\mathrm{HBO}$ was $1.1 \mu \mathrm{mol} / \mathrm{L}+/$ - SEM $0.6 \mu \mathrm{mol} / \mathrm{L}$.
The mean lactate concentration on arrival was 4.4 $\mathrm{mmol} / \mathrm{L}$. The mean lactate concentration after $\mathrm{HBO}$ was $2.5 \mathrm{mmol} / \mathrm{L}$. See Table 1.

\section{Patients from fire accidents compared with patients from non-fire accidents}

The mean WB-CN concentration on arrival did not differ significantly between the three groups of patients. See Table 2. WB-CN concentrations before and after HBO differ significantly in the three groups of patients. See Table 2.

Lactate concentrations in plasma before and after $\mathrm{HBO}$ treatments did not differ significantly in the three groups of patients.

\section{Case stories}

We found two $\mathrm{CN}$ poisoned patients with WB-CN concentrations higher than $39 \mu \mathrm{mol} / \mathrm{L}$, and include the case stories to illustrate the course of treatment following fire accidents with suspected of $\mathrm{CO}$ and $\mathrm{CN}$ poisoning.

\section{Case 1}

In 2007 a fire victim patient was transported from primary hospital to our level 1 Trauma Centre. The patient was rescued from a burning apartment where the patient was lying in a cloud of smoke up to1,5 meters. Arterial puncture at a primary hospital showed a carboxyhaemoglobin $(\mathrm{COHb})$ of $40 \%$ and lactate of $8,2 \mathrm{mmol} / \mathrm{L}$ in combination with alcohol intoxication. During ambulance transport, the patient shortly regained consciousness, but was unconscious again on arrival at primary hospital. Due to possible inhalation injuries of the upper airways, the patient was sedated with propofol and fentanyl and intubated at primary hospital before transportation to Rigshospitalet for subsequent HBO treatment. Blood tests for $\mathrm{CN}$ were taken on the arrival to Rigshospitalet including a new arterial puncture. This showed $\mathrm{pH}$ 7.33, $\mathrm{pCO}_{2} 6.6, \mathrm{pO}_{2} 6.65, \mathrm{BE} 0.2$, COHb of $17 \%$ and lactate of $4.2 \mathrm{mmol} / \mathrm{L}$. Subsequently, the patient was given $\mathrm{OHCob}$ as $\mathrm{CN}$ antidote. The WB-CN concentration before antidote treatment was $58 \mu \mathrm{mol} / \mathrm{l}$. There were plenty of soot particles in the tube; accordingly, bronco alveolar lavage (BAL) was considered, but it was decided that $\mathrm{HBO}$ had first priority. The patient received $3 \mathrm{HBO}$ therapies during the first 24 hours. After the first $2 \mathrm{HBO}$ treatments BAL was performed and showed intact mucous membranes coated with a large amount of soot particles. $\mathrm{COHb}$ normalised after the first HBO therapy to $2.8 \%$ and WB-CN concentration was $28 \mu \mathrm{mol} / \mathrm{l}$. After 24 hours the $\mathrm{CN}$ level in blood was still high $(23 \mu \mathrm{mol} / \mathrm{l})$ in spite of OHCob. During the hospitalisation the patient received 5 HBO treatments. The patient was extubated 5 days later without problems and transferred to the neurological unit. 
Table 1: Mean WB-CN, lactate and average COHgb

\begin{tabular}{|c|c|c|c|c|c|c|}
\hline & $\begin{array}{l}\text { Mean WB-CN at } \\
\text { arrival }\end{array}$ & $\begin{array}{l}\text { Mean WB-CN } \\
\text { difference before } \\
\text { and after HBO }\end{array}$ & $\begin{array}{l}\text { Mean lactate } \\
\text { before HBO }\end{array}$ & $\begin{array}{l}\text { Mean lactate } \\
\text { after HBO }\end{array}$ & $\begin{array}{l}\text { Average } \\
\text { COHgb before } \\
\text { HBO }\end{array}$ & $\begin{array}{l}\text { Average } \\
\text { COHgb after } \\
\text { HBO }\end{array}$ \\
\hline $\begin{array}{l}\text { Patients from fires } \\
\text { receiving } \mathrm{OHCob} \\
\mathrm{N}=12\end{array}$ & $15.4 \mu \mathrm{mol} / \mathrm{L}$ & $2.1 \mu \mathrm{mol} / \mathrm{L}$ & $5 \mathrm{mmol} / \mathrm{L}$ & $1.9 \mathrm{mmol} / \mathrm{L}$ & $27.9 \%$ & $2 \%$ \\
\hline $\begin{array}{l}\text { Patients from fires not } \\
\text { receiving OHCob } \\
N=13\end{array}$ & $14.33 \mu \mathrm{mol} / \mathrm{L}$ & $1.9 \mu \mathrm{mol} / \mathrm{L}$ & $3.7 \mathrm{mmol} / \mathrm{L}$ & $1.3 \mathrm{mmol} / \mathrm{L}$ & $23 \%$ & $1.9 \%$ \\
\hline $\begin{array}{l}\text { Patients from non-fires } \\
N=12\end{array}$ & $12.5 \mu \mathrm{mol} / \mathrm{L}$ & $1.1 \mu \mathrm{mol} / \mathrm{L}$ & $4.4 \mathrm{mmol} / \mathrm{L}$ & $2.5 \mathrm{mmol} / \mathrm{L}$ & $25.9 \%$ & $2.9 \%$ \\
\hline
\end{tabular}

Mean WB-CN, lactate and carbon monoxide concentrations before and after HBO therapy in all three groups. $\mathrm{N}=$ number of patients.

\section{Case 2}

An unconscious patient was rescued from a burning apartment with a Glasgow Coma Scale 3. The patient was intubated and brought to the level 1 Trauma Centre. Blood tests for $\mathrm{CN}$ were taken on the arrival including an arterial puncture for blood gas analysis. The arterial blood sample showed a $\mathrm{COHb}$ of $33.5 \%$ and lactate of 9.0 $\mathrm{mmol} / \mathrm{L}$. After the blood tests the patient received OHCob. The patient had 2 nd and 3 rd degree burns on $17 \%$ of the body, arms and face. A BAL performed in the Trauma Centre showed soot particles coating of the mucous membranes in the trachea and major bronchi. The patient was sent to the hyperbaric chamber for $\mathrm{HBO}$ treatment. Immediately before $\mathrm{HBO}$ a blood sample was taken that showed $\mathrm{pH} 7.32, \mathrm{pCO}_{2} 5.65, \mathrm{pO}_{2} 23.5, \mathrm{BE}-$ $3.7, \mathrm{COHb}$ of $10.2 \%$ and plasma-lactate of $4 \mathrm{mmol} / \mathrm{L}$. The patient received $2 \mathrm{HBO}$ treatments before being admitted to the Intensive care unit. After the first $\mathrm{HBO}$ treatment the arterial puncture showed $\mathrm{pH} 7.3, \mathrm{pCO}_{2} 6.23, \mathrm{pO}_{2}$
$11.8, \mathrm{BE}-3.6, \mathrm{COHb}$ of $3.5 \%$ and plasma-lactate of 2.8 $\mathrm{mmol} / \mathrm{L}$. The WB-CN concentration was $39 \mu \mathrm{mol} / \mathrm{l}$ before and $14 \mu \mathrm{mol} / \mathrm{l}$ after the first $\mathrm{HBO}$ treatment. Two hours after $\mathrm{HBO}$ the WB-CN concentration was 13 $\mu \mathrm{mol} / \mathrm{l}$. During the next 5 days the patient developed septic shock followed by multiple organ dysfunction syndrome caused by the severe burn injuries. On the 5 th day the patient developed hyperthermia, which was complicated by cardiovascular collapse and a fatal irreversible circulatory arrest.

\section{Discussion}

In $\mathrm{CN}$ poisoning the toxic concentration in blood has been reported to be $39 \mu \mathrm{mol} / \mathrm{L}$ and higher than 100 $\mu \mathrm{mol} / \mathrm{L}$ is potentially lethal [11]. In the group of patients from fire accidents only 2 patients had a WB-CN concentration higher than $39 \mu \mathrm{mol} / \mathrm{L}$ and 1 of those received $\mathrm{OHCob}$ before the blood test. In the group of non-fire patients none had a $\mathrm{CN}$ concentration higher than 39

Table 2: Comparison of WB-CN

\begin{tabular}{|c|c|c|c|c|}
\hline & \multicolumn{2}{|c|}{$\begin{array}{l}\text { Patients from fires receiving OHCob } \\
\mathrm{N}=12\end{array}$} & \multicolumn{2}{|c|}{$\begin{array}{l}\text { Patients from fires not receiving } \mathrm{OHCob} \\
\mathrm{N}=13\end{array}$} \\
\hline & WB-CN at arrival & $\begin{array}{l}\text { Differences in WB-CN } \\
\text { before and after HBO }\end{array}$ & WB-CN at arrival & $\begin{array}{l}\text { Differences in WB-CN } \\
\text { before and after HBO }\end{array}$ \\
\hline $\begin{array}{l}\text { Patients from fires not } \\
\text { receiving } \mathrm{OHCob}\end{array}$ & $P=0.72$ & $P=0.07$ & & \\
\hline \multicolumn{5}{|l|}{$N=13$} \\
\hline Patients from non-fires & $P=0.4$ & $P=0.16$ & $P=0.48$ & $P=0.7$ \\
\hline $\mathrm{N}=12$ & & & & \\
\hline
\end{tabular}


$\mu \mathrm{mol} / \mathrm{L}$ and only 1 patient received OHCob. Often patients were transferred to the level-1 Trauma Centre from other hospitals before $\mathrm{HBO}$ and consequently, the WB-CN blood tests were taken hours after the patients had been exposed to $\mathrm{CN}$. Following absorption $\mathrm{CN}$ is rapidly distributed throughout the body. Because of the time delay from possible $\mathrm{CN}$ exposure until blood sampling, most of the $\mathrm{CN}$ would have distributed to the tissues before the blood sample was taken. Therefore, it cannot be excluded that some of the patients who were exposed to fire have had higher concentrations of $\mathrm{CN}$ in their blood, than we were able to measure. We therefore recommend, if possible, taking the $\mathrm{WB}-\mathrm{CN}$ test at the scene of the emergency.

In an earlier study at Rigshospitalet the result was similar, showing that only 2 of 40 patients had a CN concentration higher than $39 \mu \mathrm{mol} / \mathrm{L}$ even though a greater number of patients were expected to have $\mathrm{CN}$ poisoning [22]. The study by Meyhoff et al. [22], included two control groups of which one was consisting of smokers and the other non-smokers. Their results showed that WB$\mathrm{CN}$ concentrations were marginally higher in smokers compared with non-smokers and that there were no statistical differences between these groups. Accordingly, there does not seem to be any effect of smoking on $\mathrm{CN}$ levels on whole-blood measurements. Based on these observations, the current study did not evaluate or register whether or not patients admitted with severe CO-poisoning were smokers.

The Conway method does not show how much $\mathrm{CN}$ is stored in the tissues. It has been demonstrated, that once $\mathrm{CN}$ is absorbed, the body will distribute it with $50 \%$ present in blood, $25 \%$ in muscle and $25 \%$ in other of the organs, predominantly in the liver and brain [23]. This also applies to other available methods currently used for measuring $\mathrm{CN}$ concentrations. There is a major need for a new method of measuring $\mathrm{CN}$. Because of rapid redistribution, the measured WB-CN concentration is likely to be too low.

Before $\mathrm{HBO}$ the WB-CN concentration in fire victims did not differ significantly from patients not exposed to fire or smoke inhalation. One explanation may be that the fire victims in the present study were not $\mathrm{CN}$ poisoned. This does not corresponds with earlier studies [1-4]. Another possible explanation for this observation may be found in the delay from the time of $\mathrm{CN}$ exposure and $\mathrm{HBO}$ treatment. The $\mathrm{CN}$ half-life in whole blood is only 1 hour [21]. Consequently, $\mathrm{CN}$ may be irreversibly stored in the cells by the time the patients receive HBO. This may seem at variance with the findings of Lawson-Smith et al. [20], where WB-CN concentrations measured in rats exposed to $\mathrm{CN}$ poisoning, were found to increase after HBO therapy [20]. However, in the Lawson-Smith et al. study [20], rats were exposed to significantly higher doses of cyanide and received $\mathrm{HBO}$ closer to the $\mathrm{CN}$ exposure as compared to the patients in this report. We were not able to detect any differences in WB-CN concentrations before and after HBO. Nor did the WB-CN concentrations differ significantly in the two groups. This does not mean that $\mathrm{HBO}$ treatment will not be of benefit for the patient suffering from tissue hypoxia caused by $\mathrm{CN}$ poisoning, but rather that the WB-CN concentration in our patients were too low to detect any differences before and after $\mathrm{HBO}$ therapy. In our relatively small sample, we were not able to produce a correlation between WB-CN concentrations and plasma lactate concentrations. (See Table 1) as previously demonstrated by Baud et al. [24]. Nevertheless HBO did cause a substantial reduction in plasma lactate and $\mathrm{COHb}$ (See Table 1).

Clinicians are often unable to diagnose cyanide poisoning in the emergency setting [25] and it is often difficult to find the patients with a WB-CN concentration higher than $39 \mu \mathrm{mol} / \mathrm{L}$ [11]. Clinicians often treat patients with $\mathrm{OHCob}$ because of the history of fire accident. As mentioned above, $\mathrm{OHCob}$ converts $\mathrm{CN}$ to a non-toxic substance being cyanocobalamin (B12-vitamin). Cyanocobalamin is excreted through the kidneys [13] and has a safe side effect profile making it safe to infuse even without a clear diagnose of $\mathrm{CN}$ poisoning. Side effects are red colouring of skin and urine, urticarial eczema and seldom anaphylactic chock is seen [14]. Williams et al found that $\mathrm{OHCob}$ accelerates the renal excretion of $\mathrm{CN}$ when $\mathrm{CN}$ was administered as $\mathrm{NaCN}$ [26]. Whether this is the case following $\mathrm{HCN}$ intoxication from fire accidents remains unknown.

In patients hospitalized with a history of fire accident, combined with severe neurological symptoms such as reduced Glasgow Coma Scale Scoring and either soot particles in the mouth or tracheal expectoration, is likely to be indicative of $\mathrm{CN}$ poisoning [11]. In this report, a majority of patients from fire accidents received $\mathrm{OHCob}$ as apposed to 1 patient from non-fire accidents. In keeping with the apparently safe side effect profile of $\mathrm{OHCob}$ and the damage $\mathrm{CN}$ poisoning may cause if left untreated, we recommend the use of OHCob infusion even if the WB-CN concentration has not been confirmed by direct measurement. Reports have shown that survivors of $\mathrm{CN}$ poisoning may have permanent sequelae in form of brain damage. $\mathrm{CN}$ is recognized as a cause of permanent neurological disability, ranging from various extrapyramidal syndromes to post-anoxic vegetative states [27]. This has been shown by high-resolution magnetic resonance imaging and positron emission tomography [28]. The area is not well investigated and will require more studies in the future.

Of the 25 patients admitted to the hospital from fire accidents, at least 2 patients were exposed to toxic levels of $\mathrm{CN}$. In view of the limitations with respect to the time 
delay from $\mathrm{CN}$ intoxication and WB-CN concentration measurements, we conclude that patients exposed to fire accidents may well suffer from $\mathrm{CN}$ intoxication. Accordingly, they should be treated with a suitable antidote even in the absence of verified blood $\mathrm{CN}$ measurements and preferably in combination with $\mathrm{HBO}$ treatment, the latter being the primary treatment if combined with $\mathrm{CO}$ poisoning.

\section{Competing interests}

The authors declare that they have no competing interests.

\section{Authors' contributions}

PL-S participated in the design and coordination of the study, performed the statistical analysis and drafted the manuscript. LH participated with blood sample analysis and whole blood cyanide assays. ECJ conceived of the study and participated in the design. $\mathrm{OH}$ conceived of the study, participated in the sequence alignment as well as the design and coordination of the study. All authors read and approved the final manuscript.

\section{Acknowledgements}

The authors wish to thank biotechnologist Jane Lancaster for expert technical assistance. This project would have been impossible without it. The practical assistance of taking the blood tests by the hyperbaric doctors on duty at the Centre of Hyperbaric Medicine, Rigshospitalet and laboratory staff from the Department of Clinical Biochemistry, nurses in the Trauma Center and nurses from the Intensive Care Unit is also greatly appreciated. The TRYG Foundation supported this project.

\section{Author Details}

'Laboratory of Hyperbaric Medicine, Department of Anesthesia, Center of Head and Orthopedics, Rigshospitalet, Blegdamsvej, Copenhagen, 2100, Denmark, ${ }^{2}$ Center of Hyperbaric Medicine, Department of Anesthesia, Center of Head and Orthopedics, Rigshospitalet, Blegdamsvej, Copenhagen, 2100, Denmark and ${ }^{3}$ Department of Clinical Biochemistry, Rigshospitalet, Rigshospitalet, Blegdamsvej, Copenhagen, 2100, Denmark

Received: 1 March 2010 Accepted: 15 June 2010

Published: 15 June 2010

\section{References}

1. Alarie Y: Toxicity of fire smoke. Crit Rev Toxicol 2002, 32:259-289.

2. Eckstein M, Maniscalco PM: Focus on smoke inhalation--the most common cause of acute cyanide poisoning. Prehosp Disaster Med 2006, 21:s49-s55.

3. Jones J, McMullen MJ, Dougherty J: Toxic smoke inhalation: cyanide poisoning in fire victims. Am J Emerg Med 1987, 5:317-321.

4. Baud FJ, Barriot P, Toffis V, Riou B, Vicaut E, Lecarpentier Y, Bourdon R, Astier A, Bismuth C: Elevated blood cyanide concentrations in victims of smoke inhalation. NEng/J Med 1991, 325:1761-1766.

5. Walsh DW: Hydrogen cyanide in fire smoke:an unrecognized threat to the american firefighter. Smoke, perceptions, myths, and misunderstandings 2008:4-8

6. Ikegaya H, Iwase H, Hatanaka K, Sakurada K, Yoshida K, Takatori T: Diagnosis of cyanide intoxication by measurement of cytochrome $c$ oxidase activity. Toxicol Lett 2001, 119:117-123.

7. Gorman DF, Clayton D, Gilligan JE, Webb RK: A longitudinal study of 100 consecutive admissions for carbon monoxide poisoning to the Royal Adelaide Hospital. Anaesth Intensive Care 1992, 20:311-316

8. Raphael JC, Elkharrat D, Jars-Guincestre MC, Chastang C, Chasles V, Vercken JB, Gajdos P: Trial of normobaric and hyperbaric oxygen for acute carbon monoxide intoxication. Lancet 1989, 2:414-419.

9. Weaver LK: Carbon monoxide poisoning. Crit Care Clin 1999, 15:297-317. viii

10. Weaver LK, Hopkins RO, Chan KJ, Churchill S, Elliott CG, Clemmer TP, Orme JF Jr, Thomas FO, Morris AH: Hyperbaric oxygen for acute carbon monoxide poisoning. N Engl J Med 2002, 347:1057-1067.

11. Baud FJ: Cyanide: critical issues in diagnosis and treatment. Hum Exp Toxicol 2007, 26:191-201
12. Borron SW, Baud FJ, Megarbane B, Bismuth C: Hydroxocobalamin for severe acute cyanide poisoning by ingestion or inhalation. Am J Emerg Med 2007, 25:551-558.

13. Hall $A H$, Rumack BH: Hydroxycobalamin/sodium thiosulfate as a cyanide antidote. J Emerg Med 1987, 5:115-121.

14. Megarbane B, Delahaye A, Goldgran-Toledano D, Baud FJ: Antidotal treatment of cyanide poisoning. J Chin Med Assoc 2003, 66:193-203.

15. Astier A, Baud FJ: Complexation of intracellular cyanide by hydroxocobalamin using a human cellular model. Hum Exp Toxicol 1996, 15:19-25.

16. Hall AH, Rumack BH: Clinical toxicology of cyanide. Ann Emerg Med $1986,15: 1067-1074$

17. Thom SR, Keim LW: Carbon monoxide poisoning: a review epidemiology, pathophysiology, clinical findings, and treatment options including hyperbaric oxygen therapy. J Toxicol Clin Toxicol 1989, 27:141-156.

18. Way JL, End E, Sheehy MH, De MP, Feitknecht UF, Bachand R, Gibbon SL, Burrows GE: Effect of oxygen on cyanide intoxication. IV. Hyperbaric oxygen. Toxicol Appl Pharmacol 1972, 22:415-421.

19. Gill AL, Bell CN: Hyperbaric oxygen: its uses, mechanisms of action and outcomes. QJM 2004, 97:385-395.

20. Lawson-Smith P: Treatment of Cyanide Poisoning with HBO. UHMS 2008, 35:303-304

21. Laforge M, Buneaux F, Houeto P, Bourgeois F, Bourdon R, Levillain P: A rapid spectrophotometric blood cyanide determination applicable to emergency toxicology. J Anal Toxicol 1994, 18:173-175.

22. Meyhoff CS: Rapid detection of blood cyanide concentration in victims of smoke inhalation. Rune Frandsen AHJLHaECJ 2008, 107:A1974. Anesthesiology 2007

23. Schulz V: Clinical pharmacokinetics of nitroprusside, cyanide, thiosulphate and thiocyanate. Clin Pharmacokinet 1984, 9:239-251.

24. Baud FJ, Borron SW, Megarbane B, Trout H, Lapostolle F, Vicaut E, Debray $\mathrm{M}$, Bismuth $\mathrm{C}$ : Value of lactic acidosis in the assessment of the severity of acute cyanide poisoning. Crit Care Med 2002, 30:2044-2050.

25. Kales SN, Christiani DC: Acute chemical emergencies. NEngl J Med 2004, 350:800-808.

26. Williams HL, Johnson DJ, MCNeil JS, Wright DG: Studies of cobalamin as a vehicle for the renal excretion of cyanide anion. J Lab Clin Med 1990, 116:37-44.

27. Rachinger J, Fellner FA, Stieglbauer K, Trenkler J: MR changes after acute cyanide intoxication. AJNR Am J Neuroradiol 2002, 23:1398-1401.

28. Rosenow F, Herholz K, Lanfermann $H$, Weuthen G, Ebner R, Kessler J, Ghaemi M, Heiss WD: Neurological sequelae of cyanide intoxication-the patterns of clinical, magnetic resonance imaging, and positron emission tomography findings. Ann Neurol 1995, 38:825-828.

doi: $10.1186 / 1757-7241-18-32$

Cite this article as: Lawson-Smith et al., Effect of Hyperbaric Oxygen Therapy on whole blood cyanide concentrations in carbon monoxide intoxicated patients from fire accidents Scandinavian Journal of Trauma, Resuscitation and Emergency Medicine 2010, 18:32

\section{Submit your next manuscript to BioMed Central and take full advantage of:}

- Convenient online submission

- Thorough peer review

- No space constraints or color figure charges

- Immediate publication on acceptance

- Inclusion in PubMed, CAS, Scopus and Google Scholar

- Research which is freely available for redistribution 